\title{
Evaluation of the Criteria in the Choice of Energy Storage or Non-Storage in Photovoltaic Systems in the Sahelian Zone
}

\author{
Bognini Y. Lucien', Jean B. Byiringiro², Bognini W. Abraham³ ${ }^{3}$, Gnoumou B. Aristide4, \\ Kambou Célestin ${ }^{5}$
}

\begin{abstract}
${ }^{1}$ Génie énergétique et énergie renouvelable, Distance Production House University, Ouagadougou, Burkina Faso ${ }^{2}$ DeKUT SIEMENS Mechatronics Certification Center, Dedan Kimathi University of Technology, Nyeri, Kenya ${ }^{3}$ Génie industriel et efficacité énergétique, Distance Production House University, Ouagadougou, Burkina Faso ${ }^{4}$ Génie énergie, Distance Production House University, Ouagadougou, Burkina Faso ${ }^{5}$ Génie électrique et automatique, Distance Production House University, Ouagadougou, Burkina Faso Email: bogninilucien@yahoo.com
\end{abstract}

How to cite this paper: Lucien, B.Y., Byiringiro, J.B., Abraham, B.W., Aristide, G.B. and Célestin, K. (2021) Evaluation of the Criteria in the Choice of Energy Storage or Non-Storage in Photovoltaic Systems in the Sahelian Zone. Energy and Power Engineering, 13, 236-242.

https://doi.org/10.4236/epe.2021.136016

Received: April 13, 2021

Accepted: June 12, 2021

Published: June 15, 2021

Copyright (c) 2021 by author(s) and Scientific Research Publishing Inc. This work is licensed under the Creative Commons Attribution International License (CC BY 4.0).

http://creativecommons.org/licenses/by/4.0/

\begin{abstract}
In order to have a characterization of the criteria determining the choice of energy storage or non-storage in PV systems in the Sahelian zone, we used the research methodology described as a follow-up. First, we identify the criteria that determine the choice of energy storage or non-storage. In the rest of the work, we establish a prioritization of its criteria. Finally, the two phases written above, allowed us to develop an approach characterized by the weighting of the criticality index, which we implemented using the global decision matrixes of the AMDEC method (Analysis of the Modes of Failures of their Effects and Criticism). The validation of the model followed the rigour of the scientific approach through the methodology used. Thus, the validation of the choice of the specific criteria was made on our personal experience in $\mathrm{pv}$, and the recurrence of its criteria in the literature encountered. The validation of the prioritization of the criteria is based on the quality of the results resulting from the rigorous application of the AMDEC method. This work refers to the problem of whether or not to set up an energy storage method to compensate for the off-peak periods (nights and obstacles that occur in the days) of energy production of the photovoltaic system. A determination of the determining criteria, in the choice of energy storage or non-storage in PV systems in the Sahelian zone, was made. The work also made it possible to establish a prioritization of these last criteria. The results obtained show that the proposed method allows for a prioritization of the determining criteria in the choice of energy storage or non-storage in PV systems in the Sahelian zone.
\end{abstract}




\section{Keywords}

Storage, Photovoltaic, Criticality

\section{Introduction}

The question of energy sources reveals to date, a wide variety of potential sources, on the other hand, each of the sources, for optimal production, is adapted to a given area. Fossil sources have shown their limits over time. Renewable sources, for their availability in certain areas, present themselves as a reliable alternative to the rise in prices experienced by fossil sources.

In the Sahel region, photovoltaic solar energy (PV) is increasingly used and at the same time becomes a priority in the energy investments of most governments of the countries concerned. However, this energy is linked to intermittent production. It is only insured during days without obstacles and stops at nightfall. So, for continuity of service in PV systems, a means of energy storage is often necessary. It is in this spirit that a decision is needed, whether or not it is to put in place a means of energy storage.

Solar PV energy is experiencing a significant increase in the world, and particularly in the Sahelian zone south of the Sahara, in Africa. In Burkina Faso, there is a growing risk of injecting renewable and hybrid energy production into the interconnected national grid. The largest injection renewable energy plant in the national grid is the 33MWc ZAGTOULI photovoltaic plant inaugurated on 29 November 2017 [1]. This plant is without storage, so produces no energy at times without sunshine like nights. Burkina Faso also saw the inauguration on 19 March 2018 of the world's first solar power plant, which is twinned with an energy plant. It is the work of a mining company, located in the Sahelian area located in the north of the country. It is a $15 \mathrm{mWc}$ solar power plant paired with a $57 \mathrm{~mW}$ power plant, which comes from the ESSAKANE mine owned by the IAMGOLD group [2].

In our work, we highlight a set of important criteria in the choice of energy storage or non-storage in PV systems in the Sahelian zone. Many other research studies have already taken into account the categorization of the energy storage methods of PV systems. On the other hand, we have not encountered in the literature, a study focused particularly on the criteria determining the choice of a storage or non-storage means, or even their prioritization. So this work, by its presented results, positions itself as a reference in decisions on whether or not to set up a storage medium in PV systems.

\section{Determinative Criteria in the Choice of Energy Storage or Non-Storage in Photovoltaic Systems in the Sahelian Zone}

The choice of the determining criteria was made in a careful observation among the parameters that can influence the establishment of storage in photovoltaic 
systems. Thus, the following parameters were considered the most sensitive in setting up storage:

- Storage costs: the installation of storage to compensate for off-peak periods (nights, climatic hazards, ...) is subject to significant costs that are based on storage technology. The cost of storing in a PV system with batteries as a storage technology can account for $40 \%$ of the total investment [3].

- The cost of maintaining storage means: storage often requires regular monitoring and its frequency depends on the storage technology used.

- Environmental aspects related to storage: the choice of storage technology must integrate health safety and consideration of the work environment.

- The technological characteristics of storage: efficiency, adaptability to PV and autonomy are technical and economic characteristics that influence accessibility to different storage methods [4].

- The selling price of PV energy produced: the profitability of energy production for private structures is directly linked to the cost price of $\mathrm{kWh}$.

\section{Quantitative Analysis of the Determining Criteria in the Choice of Energy Storage or Non-Storage}

This is the characterization phase of the determining criteria in the choice of energy storage or non-storage. It aims to prioritize the determining criteria for whether or not to store energy in order of criticality index [5]. Criticality is the combination of the occurrence of the criterion, the severity of the effect generated and the choice on storage.

The criticality of an event is the product of gravity, occurrence and choice. Criticality can be expressed by the following equation:

$$
C=G \times O \times C h
$$

The hierarchy is given in order of decreasing criticality, which means that the highest value corresponds to the strongest criticality.

Table 1 provides a reading of the rating tools that will be used to determine the values of the criticality index.

\section{Analysis of the Failure Modes of Their Effects and Criticism}

After determining the rating tools, we relied on our personal experience on the one hand, and on the other hand on the assessments of PV project management and design experts to complete Table 2.

Table 2 shows that each of the criteria identified can involve one or more modes of failure. Thus, the storage cost criterion corresponds to two modes of failure, the installation costs of only storage are higher or equal to the costs of other components of the PV system, and a failure related to an excessive replacement of the means of storage. The second criterion, which is the maintenance of storage means, is related to a single mode of failure which is monitoring and monitoring. The third criterion, which is the environment, is associated 
Table 1. Rating of assessment tools.

\begin{tabular}{ccccc}
\hline \multirow{2}{*}{ Note } & \multirow{2}{*}{ Gravity scale } & Occurrence scale & \multicolumn{2}{c}{ Choice scale } \\
\cline { 4 - 5 } & & Choice & Note \\
\hline 1 & No influence & Very Unlikely & Yes & 2 \\
2 & Significant situation & unlikely & & 1 \\
\hline 3 & Worrying situation & Possible & Indécision & \multirow{2}{*}{ No } \\
\hline 4 & Irreversible situation & Probable & No & \\
\hline 5 & Extravagant situation & Very Likely & & \\
\hline
\end{tabular}

Table 2. AMDEC study on photovoltaic storage.

\begin{tabular}{|c|c|c|c|c|c|c|c|c|}
\hline Criterion & Explication & Modes of Failures & Causes & Effects & G & $\mathrm{O}$ & Choix & $\mathrm{C}$ \\
\hline \multirow[t]{2}{*}{ Cost of Storage } & \multirow[t]{2}{*}{ Setting up } & $\begin{array}{l}\text { Fees higher or equal to } \\
\text { other components }\end{array}$ & Storage specificity & $\begin{array}{l}\text { Storage is inappropriate in } \\
\text { the short to medium term }\end{array}$ & 3 & 2 & 2 & 12 \\
\hline & & Excessive change & Short lifespan & Storage is expensive & 3 & 2 & 2 & 12 \\
\hline Maintenance & $\begin{array}{l}\text { Monitoring } \\
\text { and monitoring }\end{array}$ & Tracking failures & Irregularity and misdiagnosis & Storage is expensive & 3 & 3 & 1 & 9 \\
\hline \multirow{2}{*}{ Environment } & \multirow{2}{*}{$\begin{array}{l}\text { Relationship with } \\
\text { the environment }\end{array}$} & Harmful to health & $\begin{array}{c}\text { Presence of products } \\
\text { harmful to health (explosive } \\
\text { gas, lead, acid) }\end{array}$ & Storage is dangerous & 2 & 2 & 2 & 8 \\
\hline & & Bulky for space & $\begin{array}{l}\text { Sureté d'espace de stockage } \\
\text { avec un cycle élevé } \\
\text { de renouvellement }\end{array}$ & Storage is annoying & 1 & 1 & 2 & 2 \\
\hline \multirow{4}{*}{ Technology } & \multirow{4}{*}{$\begin{array}{c}\text { Technical } \\
\text { features and use }\end{array}$} & Bad adaptation for PV & $\begin{array}{l}\text { Immature technology not } \\
\text { recommended for PV }\end{array}$ & Storage is unfeasible & 5 & 5 & 3 & 75 \\
\hline & & Limited autonomy & Undated capacity & Storage is expensive & 2 & 2 & 2 & 8 \\
\hline & & $\begin{array}{l}\text { Unsatisfactory } \\
\text { performance }\end{array}$ & $\begin{array}{c}\text { Current state of } \\
\text { insufficient research }\end{array}$ & Storage is expensive & 2 & 2 & 2 & 8 \\
\hline & & $\begin{array}{l}\text { Poorly controlled } \\
\text { technology }\end{array}$ & $\begin{array}{l}\text { Difficult to take } \\
\text { control of users }\end{array}$ & Storage is annoying & 2 & 2 & 2 & 8 \\
\hline \multirow{2}{*}{ Cost } & \multirow{2}{*}{ Costs for resale } & $\begin{array}{l}\text { Unsatisfactory } \\
\text { resale costs }\end{array}$ & $\begin{array}{l}\text { Monopoly not advantageous } \\
\text { to other producers }\end{array}$ & Storage is expensive & 2 & 2 & 2 & 6 \\
\hline & & $\begin{array}{c}\text { Unregulated } \\
\text { and risky market }\end{array}$ & $\begin{array}{l}\text { A neglected sector } \\
\text { with investment risks }\end{array}$ & Storage creates more risks & 3 & 3 & 1 & 9 \\
\hline
\end{tabular}

with two modes of failure. This is the question of the health harmfulness of the means of storage, and the clutter of the premises [6]. The penultimate criterion, which is the technological characteristic of storage means, is, combined with four modes of failure, in view of its sensitivity. Poor storage adaptation for a PV system, low battery life of the storage system, insufficient efficiency of the storage method and poorly controlled technology or maturity of the storage medium are the modes of failure associated with this fourth criterion [7]. The last criterion, the cost price per kWh of energy produced by a PV system, is combined with two modes of failure. For example, an unsatisfactory resale price and an unregulated market have been identified as the two modes of failure asso- 
ciated with this fifth and final criterion.

\section{Evaluation and Prioritization of the Determining Criteria in the Choice of Energy Storage or Non-Storage}

A weighting is made with the failure modes of each of the determining evaluation criteria. This gives us Table 3.

The various criteria that were the subject of the study were isolated by their rating on criticality and presented in Table 3 . Depending on the highest criticality, we ranked the different criteria of the study. Thus, we describe below the ranking followed by an interpretation.

1st place: this place is occupied by the choice of storage technology. This criterion refers to the type of storage to be done for the PV system. This criterion seems to merit its overriding place in the decision whether or not to set up storage in a PV system. There are several types of technology for the means of storage of PV systems [8].

2nd place: occupied by the cost of storage, this criterion also proves its sensitivity in the decision to establish or not a means of storage by positioning itself in second place. The installation costs associated with storage are often very high. The higher the capacity, the higher the storage costs [4].

3rd place: resale costs rank third in the order of the criteria for the implementation of storage in PV systems. This criterion is related to the operation of the system [9]. This operation is intended to cover the cost of installing the entire system according to the system's component depreciation program. There are a few types of pricing structures adapted to PV systems [10].

4th place: the environmental component is ranked in the penultimate place, in consideration for introducing storage. This may result, as so far, this component seems to be less considered compared to the other criteria of the study in the choice of storage.

Table 3. Prioritization of the determining criteria in the choice of energy storage or non-storage.

\begin{tabular}{cccc}
\hline Criteria & Criticism by failure mode & Weighting criticality & Rank \\
\hline Storage cost & 12 & 24 & $2^{\text {eme }}$ \\
\hline Maintenance & 12 & 9 & $5^{\text {eme }}$ \\
\hline Environment & 9 & 10 & $4^{\text {eme }}$ \\
\hline Technology & 2 & & $1^{\text {er }}$ \\
& 75 & 97 & \\
Resale price & 8 & & $3^{\text {eme }}$ \\
\hline
\end{tabular}




\section{RANKING STUDY CRITERIA}

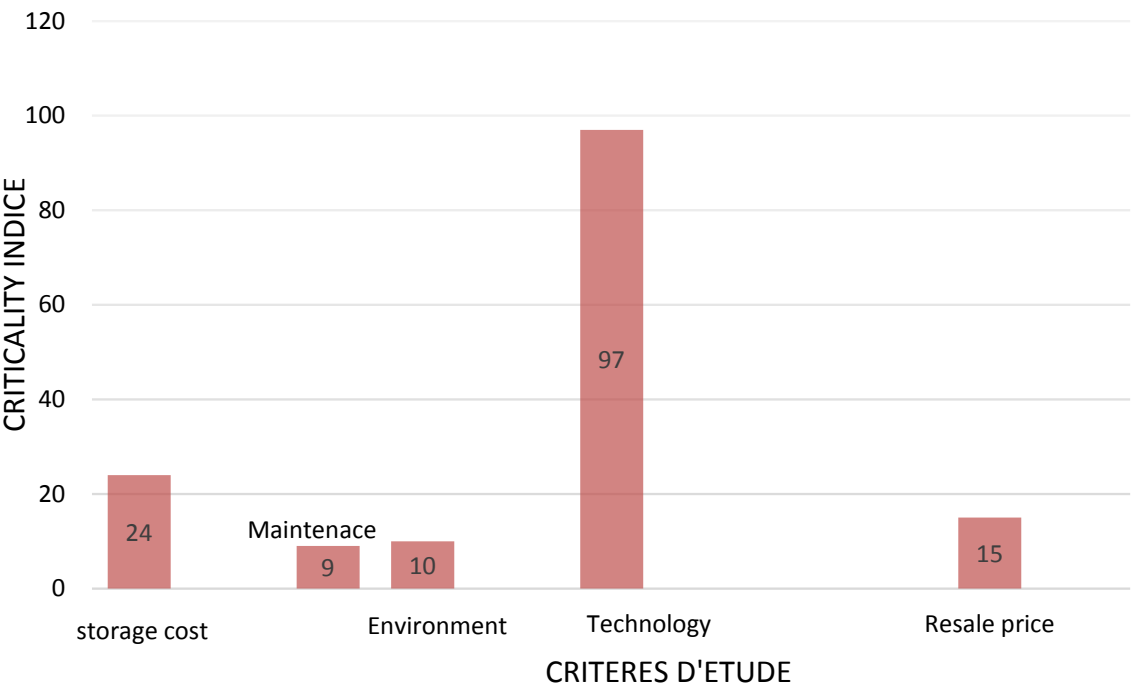

Figure 1. Ranking of study criteria according to the criticality index.

5th place: the last place is occupied by the maintenance component of the storage facilities. This can be explained by the peculiarity of the Saharan zone. In this area, the majority of storage facilities used in PV systems are without intermediate maintenance until the end of their life.

We then make a ranking of our criteria through a given diagram in the following Figure 1.

Figure 1 gives us a better understanding of the ranking of study criteria discussed in Table 3. The elements of appreciation already mentioned on the previous classification remain valid for a possible interpretation of Figure 1.

\section{Conclusions}

This study, which assesses the criteria for whether or not to store energy in photovoltaic systems in the Sahel region, identified and prioritized the criteria most sensitive to the issue of storage. Thanks to a bibliographical research approach, we were able to identify five criteria, the most sensitive and part of the decision on whether to set up a storage. The five criteria that caught our attention in the study were the cost of installing or setting up storage, the cost of maintaining the storage medium, the environment component resulting from storage, storage technology, and the cost of the kWh of energy for commercialization. In the prioritization of these criteria, the study found that, according to the criticality index, the criterion of storage technology is the most sensitive for any reflection on the implementation of a storage.

Where possible, these results should be confirmed by an experimental study for PV systems.

\section{Conflicts of Interest}

The authors declare no conflicts of interest regarding the publication of this paper. 


\section{References}

[1] Direction Générale des Etudes et des Statistiques Sectorielles (2019) Tableau de bord 2018 du ministère de l'énergie du Burkina Faso. Réalisé avec l'appui du PAGPS financé par l'Union européenne.

[2] Total Eren (2018) Le Burkina Faso.

[3] Azoumah, Y. (2012) Mix énergétique et intelligents. Cours de technologie solaire, 2ie.

[4] Korsaga, E., Koalaga, Z., Bonkougou, D. and Zougmore, F. (2018) Comparaison et détermination des dispositifs de stockage appropriés pour un système photovoltaïque autonome en zone sahélienne. hal-01713810.

[5] Iberraken, F. and Maouche, C. (2012) Analyse des Modes de Défaillance des Systèmes Photovoltaïques installés dans le sud Algérien. Mémoire de master.

[6] Blum, A.F., and Long Jr., R.T. (2016) Évaluation des dangers liés aux systèmes de stockage d'énergie utilisant des batteries lithium-ion. Rapport final, LA FIRE PROTECTION RESEARCH FOUNDATION.

[7] Chen, H., Cong, T.N., Yang, W., Tan, C., Li, Y. and Ding, Y. (2009) Progress in Electrical Energy Storage System: A Critical Review. Progress in Natural Science, 19, 291-312. https://doi.org/10.1016/j.pnsc.2008.07.014

[8] Kabouche, R., Harrouni, S. and Talha, A. (2012) Etude Comparative des Différentes Techniques de stockage de l'énergie photovoltaïque. le $2^{\text {ème }}$ Séminaire International sur les Energies Nouvelles et Renouvelables.

[9] azimut360 (2017) Micro-réseaux photovoltaïques hybrids. Guide de conception et calcul (Juillet 2017), ECREEE.

[10] Lefrou, C., Dulout, J., Jammes, B. and Alonso, C. (2015) Critères de choix d'un système de stockage électrochimique hybride d'énergie photovoltaïque. HAL Id: hal-01178996. 